\title{
Volleyball Smash Learning Model for Middle School Students
}

\author{
Weni Wiliya Budiarti ${ }^{1}$, Achmad Sofyan Hanif ${ }^{2}$, Samsudin $^{3}$ \\ ${ }^{1,2,3}$ State University of Jakarta, Indonesia \\ weniwiliyabudiarti@yahoo.com
}

\begin{abstract}
This research was conducted to produce a volleyball smash learning model and test its effectiveness for junior high school children. The development method adopts the development steps of Borg and Gall. Small group trials involve 15 athletes and 60 for large group trials. The development of the model begins with small trials, large trials and effectiveness tests. The effectiveness test used pre-posttest with the instrument of the volleyball smash skills of junior high school students. The exercise model that was applied was tested for the significance of the difference and it was obtained that the t-test $=31,614, d b=32$ and $p$ value $=0.00<0.05$, meaning that there were significant differences in the ability of students before and after they were given the volleyball smash learning model. It was concluded that existing model could be developed and applied in volleyball smash learning and effectively improved volleyball smash learning outcomes for junior high school students.
\end{abstract}

Keywords: Model development; learning; volleyball; junior high school.

\section{Introduction}

Achievements in sports are indicators to show the characteristics of a region or nation in responding to the challenges of globalization in all fields at present, both at national and international levels. Achievements in the field of sports are reflected in the success of coaches in each branch or parent of sports organizations when winning a championship (Atmasubrata, 2014). The success of the system process is determined by the quality improvement in training and learning conventionally must change gradually with the presence of age. Maximum results that cannot be achieved is the biggest challenge for a coach. For coaches this is a weakness both during training and during matches. Through this observation the authors conclude that especially in junior high schools the authors find obstacles where junior high school students still have weaknesses and imperfect smash, service / spike, passing, due to lack of practice that has a high level of difficulty.

Learning is a combination of teaching activities carried out by teachers and learning activities carried out by students. In these learning activities, there is interaction between students and students, interactions between teachers and students, and interactions between students and learning resources. It is expected that with these interactions, students can actively build knowledge, learning takes place interactively, inspiring, fun, challenging, and can motivate students to achieve the expected competencies (Irawan, et al: 2019).

Volleyball games in Indonesia today can be said as sports that have been community, so the government seeks in order to develop sports activities as an effort to physical and spiritual development, the government is trying to popularize sports and community sports (Hernawan, 2016). The motto that has been echoed and the development of sport above has an impact on the growth and development of sports which is a manifestation of the government's exception in expanding sports as a means to maintain and improve the physical fitness of the community and in the context of fostering the nation and developing the country (Barbara \& Bonnie, 2010).

Volleyball game is a sport that aims to improve physical fitness and the development of sports achievements, therefore efforts to improve and develop volleyball learning achievements need to be practiced to improve desired performance (Ferguson, 2010). Volleyball is a sport that dominates the entire community, both students and government agencies, where the 
development of volleyball is very rapid, this can be seen from the implementation of volleyball championships at elementary, middle, high school and general level often held.

Volleyball sports consist of various forms of movements which are a very important basis in volleyball games, such movements include service movements, passing movements, passes and smash / spike movements. That move must be mastered by every volleyball player. Then the smash in volleyball game is a form of series of movements performed by a player with the aim of crossing the ball towards the opponent while turning off the opponent's game and getting points.

Volleyball is a sport that is quite popular in Indonesia. Volleyball is also expected to bring the name of the nation and state to an international event. But the facts show that volleyball performance in Indonesia in general is still relatively low (Muril, 2009).

In volleyball games required various elements of physical conditions, such as: Strength, speed, agility, balance of explosive power and others. All components are needed to support game activities such as: Jumping, blocking, smash, defense. The optimal vertical jump height will make it easier for a volleyball player to block and smash. For this reason, every volleyball player is demanded to have the perfect jumping ability (Hernawan \& Widyaningsih, 2018).

Mastery Motion skills are very important in volleyball games, if mastery of good and correct motion in accordance with basic techniques will get the desired results (Rendy et al, 2018). The ability to jump must be developed in every volleyball player. Many ways you can do to improve your perfect jumping ability. To be able to leap up and make fast movements to the maximum required explosive power.

One method for developing explosive power is through plaiometric training. Plaiometric training is a form of exercise that stimulates the muscles to do work activities quickly. Plaiometric training activities consist of: Knee tuck jump, squat jump, box jump, split squat jump and depth jump.

The smash technique is the most difficult technique in volleyball because it requires good physical condition and maximum coordination of motion. Smash requires strong power and proper timing (Robert, 2009). To get all of that is not easy and requires repetitive training to perfect the smash technique. The smash technique is the core or the tip of an attack that is built by a team to get points and also the most often done to get points.

The smash training model is an exercise that is used by trainers or teachers to provide different material to athletes or also to students to avoid boredom and also boredom in training. Each trainer in developing an exercise program must think about variations in the training menu. Because the training model is very important to maintain the interest and activeness of athletes in following the process of training activities. As for the steps to make a smash as follows: Prefix, Repulsion, Ball Punch, Landing Attitude (Setyo, 2009), Judging from its understanding Smash can be defined as a how to play the ball effectively and efficiently to get optimal results, but stick to the rules of the game that has been applied. So the smash in volleyball is a form of a series of movements carried out by a player with the aim of crossing the ball towards the opponent while turning off the opponent's game and getting numbers and an attack technique that is done by hitting the ball and aims to place the ball into the area of the opposing team without being able to be locked or returned by the opponent, thus killing the opponent and of course adding value or points from the team.

Quality learning is very dependent on student motivation and teacher creativity. Therefore the success of a learning depends on the way the teacher delivers the learning model to students so that the role of a teacher is required to be able to be creative and innovate with 
various learning models that attract students to be motivated to learn with enthusiasm, so that the main target in learning will be achieved quickly (Hamdani, 2009).

Based on the description above, therefore researchers want to contribute to making a creative and innovative learning model so that learning objectives can optimally provide examples of implementation to teachers in delivering material in physical education learning about the smash and service learning model of jumps in volleyball games and develop training models or variations of movements to improve smash techniques as a solution to overcome existing problems.

\section{Research Methods}

This research development uses the Research \& Development (R\&D) method from Borg and Gall with the subject of 70 students from 4 first-level schools. Data collection techniques are done by observation, documentation study, interviews, and tests. Data analysis was carried out qualitatively and quantitatively. After going through a small trial with 20 subjects included, large trials included 60 subjects and the effectiveness test. Test the effectiveness of the model in the study using a significance test Pre-test and Post-test based on the stages of learning volleyball smash techniques. To find out the value of the effectiveness of the existing data was tested using paired sample t-test with SPSS 16.0 which was previously calculated the normality value of each group. The instrument used in this study was a test result of volleyball smash learning skills for junior high school students. The instruments created were validated by physical education learning experts, volleyball game experts and evaluation experts, sports measurement tests. The design or design model that the researcher developed is the development design proposed by Borg and Gall (Borg \& Gall, 2004).

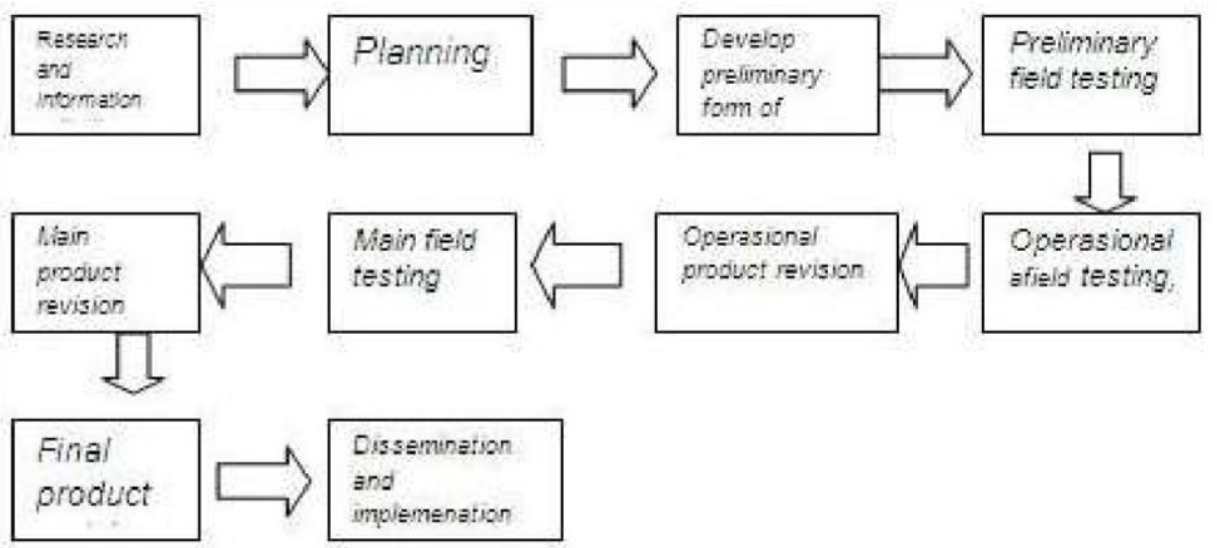

Figure 1. Step of Borg \& Gall's research and development

The steps of Borg \& Gall are described as follows, (1) research and information gathering. Researchers conduct observations, questionnaires and interviews about the needs of students' movements and problems faced by the trainer, (2) planning, then it needs to be collected various information that can be used as material for planning, (3) product development, researchers design products to develop volleyball smash learning model development adjusted to the needs of movement and characteristics at junior high school age, (4) initial product field testing by including 15 subjects, (5) operational field testing, (6) based on the results of the initial product 
analysis, revised so that it becomes a better product, repaired or revised after weaknesses were identified, (7) large group field tests of 60 subjects, (8) product revision of large group test results (9), effectiveness test of 70 students to determine whether the development of the volleyball smash learning model was developed effectively for the first school, (10) dissemination and me report the final product of research and development after the end result has been improved.

\section{Results and Discussion}

Researchers conducted a preliminary test before giving the volleyball smash learning model and afterwards giving training models as many as 25 models using the final volleyball smash learning outcomes test. The effectiveness test was carried out with a Pretest and Posttest by including 70 treatment and control groups each. It can be seen in table 1 that the average pretest and posttest results of learning volleyball smash skills are 50.756 and 86.616. Then the average difference test is performed using a paired sample test (t-test), the test must be preceded by a normality test. Because as many subjects, the normality test uses Shapiro-Wilk SPSS 16.0 with the results of the pre-test and post-test have p-value sig. 0.125 and 0.241 , which shows values more than $\alpha=0.05$, meaning that the data are normally distributed. Calculation of the normality test is shown in table 1 . As in table 3 , the correlation coefficient of the game before and after treatment is 0.148 with a p-value of $0.00<0.05$, meaning that it is significant.

Table 1. Normality Test

\begin{tabular}{|c|c|c|c|c|c|c|c|}
\hline $\mathrm{Ex}$ & mental K & $\operatorname{lmog}$ & ov-s & nov $^{\mathrm{a}}$ & hapirc & Wilk & Knowledge Statistic d \\
\hline Stat & c df Sig. & & & & & & \\
\hline & Pre-test & .135 & 70 & .089 & .923 & 70 & .125 \\
\hline Result & & & & & & & \\
\hline & Post-test & .222 & 70 & .101 & .854 & 70 & .241 \\
\hline
\end{tabular}

a. Lilliefors Significance Correction

Table 2. Paired Samples Statistics

\begin{tabular}{|c|c|c|c|c|c|}
\hline & & Mean & $\mathrm{N}$ & $\begin{array}{c}\text { Std. } \\
\text { Deviation }\end{array}$ & $\begin{array}{c}\text { Std. Error } \\
\text { Mean }\end{array}$ \\
\hline \multirow{2}{*}{ Pair 1} & Pre-Test & 50.756 & 35 & 9.272 & 1.382 \\
\hline & Post-Test & 86.616 & 35 & 9.129 & 1.361 \\
\hline
\end{tabular}

Table 3. Paired Samples Correlations

\begin{tabular}{|c|c|c|c|c|}
\hline Pair 1 & $\begin{array}{c}\text { Pre-Test and } \\
\text { Post-Test }\end{array}$ & 70 & .148 & .331 \\
\hline
\end{tabular}


Table 4. Paired Samples Test

\begin{tabular}{|c|c|c|c|c|c|c|c|c|}
\hline \multirow{3}{*}{ Pair 1} & \multicolumn{5}{|c|}{ Paired Differences } & \multirow{3}{*}{$\mathrm{t}$} & \multirow{3}{*}{$\mathrm{df}$} & \multirow{3}{*}{$\begin{array}{l}\text { Sig. (2- } \\
\text { tailed) }\end{array}$} \\
\hline & Mean & $\begin{array}{c}\text { Std. } \\
\text { Deviation }\end{array}$ & $\begin{array}{l}\text { Std. } \\
\text { Error } \\
\text { Mean }\end{array}$ & $\begin{array}{r}95 \\
\text { Confic } \\
\text { Interval } \\
\text { Differ }\end{array}$ & $\begin{array}{l}\% \\
\text { lence } \\
\text { of the } \\
\text { ence }\end{array}$ & & & \\
\hline & & & & Lower & Upper & & & \\
\hline $\begin{array}{l}\text { Pre-Test } \\
\text { Post-Test }\end{array}$ & 39.33 & 12.00 & 1.79 & 42.94 & 35.72 & 15.611 & 32 & .000 \\
\hline
\end{tabular}

Significance test the difference through SPSS 16 in table 4 obtained the results of t-count $=15.611, \mathrm{db} 32$ and $\mathrm{p}$-value $=0.00<0.05$. This means that there are significant differences in the results of learning volleyball smash skills after being treated the game that was developed. Because the $\mathrm{N}$-gain score (\%) shows the number $75.9 \%$ with the effective category, it can be said that the learning model developed is effective and can improve the volleyball smash skills of schoolchildren in first place significantly.

The increase can occur because the model adopted is in accordance with the character and needs of students at the junior high school level. The increase in learning outcomes on the subject is an indicator of success in each of the stages in the Borg and Gall step. The researcher conducts the stages in detail and includes empirical data for a more extensive assessment. Volleyball learning is normally done in several stages, because in it there is motor adaptation in controlling new movements that were not previously recorded by the brain (Setyosari, 2010). Robert (2009) in his research explained that to master a new technique in a movement can be done with systematic learning, done repeatedly and carried out in several stages. This is in accordance with the adoption of the model made by researchers that emphasizes the systematic rules of items in learning from the easiest to the most difficult and from the simplest to the most complex. Other studies that support the effectiveness of the smash learning model are conducted (Fatirul, Hernawan \& Hidayat, 2018) as quoted, "the training model for volleyball for beginners is effective to improve the ability to defense volleyball". In addition, systematic learning stages can have a positive influence on volleyball smash learning outcomes. Another statement supporting this is the quote made (Hernawan \& Ridzqi, 2018) that, "there was a significant difference of the jump service ability between the group of barrier hops method and the group of box jump method who had low power of the muscle of the limbs ".

\section{Conclusion}

Based on the data obtained from the results of small group trials, field tests and discussion of research results, it can be concluded that.

1. The development of this volleyball smash learning model in the form of 25 items which have been recorded in which there are learning designs and objectives according to core competencies and basic competencies in the middle school arena which can assist teachers in carrying out the learning process effectively and efficiently. 
2. The developed learning model is able to improve learning outcomes and is effective to be applied to primary school students with a significance value of t-count $=15.611, \mathrm{db} 32$ and $\mathrm{p}$-value $=0.00<0.05$.

\section{References}

Atmasubrata, G. (2014). Serba Tahu Dunia Olahraga. Surabaya: Dafa Publishing.

Abrasyi, R., Sujiono, B., Hernawan and D. (2018). Model Latihan Passing Bawah Bola Voli Pada Siswa Sekolah Menengah Pertama. Gladi Jurnal Keolahragaan2, 3(1), 110-120.

Borg, W., R. and Gall, M. (2004). Educational Research an Introduction. New york: Logman. Ferguson, B., L., V. and B. J. (2010). Volleyball Step to Succes Second Edition. Canada: Human Kinetics.

Hamdani. (2009). Strategi Belajar Mengajar. Jakarta: Rineka Cipta.

Hernawan, H. (2016). Model Kegiatan Outdoor Games Activities Untuk Mahasiswa Program Studi Olahraga Rekreasi Fakultas Ilmu Keolahragaan Universitas Negeri Jakarta. In Prosiding Seminar dan Lokakarya Fakultas Ilmu Keolahragaan Universitas Negeri Jakarta (Vol. 1, No. 01, pp. 28-35).

Hernawan and Ridzqi. (2018). Pengaruh Metode Latihan Dan Power Terhadap Kemampuan Jump Service Bola Voli. Jurnal Ilmu Keolahragaan, 09(02): 108-118. https://doi.org/10.21009/GJIK.092.04

Hernawan, H., \& Widyaningsih, H. (2018). Model Outdoor Games Activities Untuk Pemuda Karang Taruna Tenaga Penggerak Olahraga Rekreasi. Fakultas Ilmu Olahraga. Universitas Negeri Jakarta. 2018. In Prosiding Seminar dan Lokakarya Fakultas Ilmu Keolahragaan Universitas Negeri Jakarta (Vol. 3, No. 01, pp. 28-33).

Irawan, A., Ruslan, D., and Simare mare, A. (2019). The Effects of Learning Models of Discovery Learning and Learning Interest on Social Science Learning Outcomes in Grade VII of Junior High School of Al-Azhar Medan. Budapest International Research and Critics in Linguistics and Education Journal, Vol. 2 No. 3, 94-105.

Muril, A. (2009). Panduan Olahraga Bolavoli. Jakarta: Era Pustaka Utama.

Maribe, R., B. (2009). Instructional Design: The ADDIE Approach. new york: Simon \& Schuster Custom Publishing,.

Setyo, B. (2009). Dasar-dasar Metodologi Penelitian dalam Ilmu Keolahragaan. Malang: PT Departemen Pendidikan Nasional Universitas Negeri Malang Lembaga Penelitian.

Setyosari, P. (2010). Metode Penelitian Pendidikan dan Pengembangan. Jakarta: Kencana.

Viera, B., L., and Ferguson, B., J. (2010). Volleyball Step to Succes Second Edition. Canada: Human Kinetics.

Wa'asil, F., Hernawan, H., H. (2018). Defense Exercise Model Of Volleyball FW. Jurnal Pendidikan Olahraga. 7(2): 96-103. https://doi.org/10.3157/jpo.v7i2.1166 